\title{
Reevaluating the effects of soil organic matter and other properties on available water-holding capacity using the National Cooperative Soil Survey Characterization Database
}

Z. Libohova, C. Seybold, D. Wysocki, S. Wills, P. Schoeneberger, C. Williams, D. Lindbo, D. Stott, and P.R. Owens

\begin{abstract}
Soil organic matter (SOM) has been known to hold water and be an important factor in contributing to the available water-holding capacity (AWHC). Recently, however, there have been overestimates of this amount. The objective of this research was to reevaluate the relative contribution of SOM to AWHC as influenced by soil physical properties (particle size, texture, and bulk density) and mineralogy using the National Cooperative Soil Survey (NCSS) Soil Characterization Database and also to elucidate on the theoretical capacity of SOM to hold water. Silt content had the greatest correlation with AWHC $(r=0.56)$. AWHC increased with decreasing soil bulk density $(r=-0.34)$, but the relationship was highly variable depending on SOM and soil texture. Soil organic matter was weakly correlated with AWHC for samples between $0 \%$ and $8 \% \operatorname{SOM}(r=0.27)$ but moderately correlated $(r=0.62)$ for all samples $(0 \%$ to $100 \%$ SOM). The increase of AWHC was more pronounced for sandy soils than for silty clay loam and silt loam soils. For soils with clay contents greater than $40 \%$, the correlation varied by minerology class: mixed $(r=0.24)$, smectitic $(r=0.08)$, and kaolinitic $(r=0.49)$. In general, a $1 \%$ increase in SOM content increased AWHC, on average, up to $1.5 \%$ times its weight, depending on soil texture and clay mineralogy. These values were consistent with the theoretical calculations that showed that the potential AWHC increase (on a volumetric basis) from a unit increase in SOM (\% weight) is about $1.5 \%$ to $1.7 \%$ for the $0 \%$ to $8 \% \mathrm{SOM}$ range. This equates to $10,800 \mathrm{~L}$ of water for each additional $1 \%$ increase in SOM (up to $8 \% \mathrm{SOM}$ ) for a layer thickness of $15 \mathrm{~cm}$ covering 0.4 ha area (an acre furrow slice).
\end{abstract}

Key words: soil mineralogy—soil organic matter—soil texture—soil water-holding capacity

\begin{abstract}
Available water-holding capacity (AWHC) is the quantity of water stored in a soil that is available to plants through their root systems. It is commonly defined as the amount of water held between field capacity and wilting point, with adjustments made for salinity, fragments, and rooting depth (Soil Survey Staff 2017). Field capacity is the water content held in soil after excess water has drained away, through the soil profile, when the rate of downward movement becomes negligible (SSSA 2008). It is important to distinguish between AWHC and total soil water storage, the latter representing the maximum amount of water soil can accommodate as determined by total soil porosity and commonly associated with sat-
\end{abstract}

The WRD has utility for many agronomic purposes and for measuring relative differences in AWHC within and among soils (Bauer and Black 1992). Information about the amount of available water that can be retained by soil has numerous important uses in management and soil survey interpretations (Cassel and Sweeney 1974).

Soil organic matter (SOM) has a high moisture retention capacity and is an important factor in contributing to AWHC, which has practical implications for soil water management, especially for agricultural purposes (Stone and Garrison 1940). Recently, there have been overestimates of the amount of water that SOM increase can contribute to AWHC. Several overstated values have been used to underscore the influence of SOM on soil water-holding capacity, for example, " $1 \%$ organic matter stores 25,000 $\mathrm{gal} \mathrm{ac}^{-1}\left[233,750 \mathrm{~L} \mathrm{ha}^{-1}\right]$ and $1 \mathrm{lb}[0.45 \mathrm{~kg}]$ of organic matter can hold $20 \mathrm{lb}$ [9 kg] of water" (Stevenson 1994; Knapp et al. 2012; Mengel 2012). Are these values scientifically credible? The confusion stems from the numerous, and often contradictory, evaluations or predictions of the magnitude of SOM contribution to AWHC, and amount of water that can be held by SOM.

Studies have shown that a $1 \%$ increase in SOM (on weight basis) can increase the soil water content within the AWHC range to varying degrees, depending on soil texture (Hudson 1994; Emerson et al. 1994; Emerson 1995; Hamblin and Davies 1977; Russell and Shearer 1964; Barrow 1969; Russell et al. 1952; Rose 1991). Emerson (1995) showed that SOM could potentially contribute about $2.2 \%$ to $12.5 \%$ of the available water, depending on soil texture and land treatment (in a Natrixeralf). Olness and Archer (2005), using soils from the USDA Natural

laboratory, field capacity is determined as water held at $-33 \mathrm{kPa}$ tensions for clayey and loamy soils and $-10 \mathrm{kPa}$ tensions for sandy soils. Wilting point is defined as the water content at which the soil is no longer able to transfer water toward the roots at a rate that maintains plant turgor (for agronomic crops). It is determined in the laboratory as water held at $-1,500 \mathrm{kPa}$ tensions (Romano and Santini 2002). Soil microorganisms may be able to utilize water held at tensions greater than the wilting point (Stott et al. 1986), but most likely at a greater energy cost. The difference between the water held at $-33 \mathrm{kPa}$ and $-1,500 \mathrm{kPa}$ tensions is also referred to as the water retention difference (WRD).
Zamir Libohova is a research soil scientist, Cathy Seybold is a soil scientist, Doug Wysocki is a national leader, Skye Wills is a soil scientist, Phil Schoeneberger is a research soil scientist, and Candiss Williams is a research soil scientist, all with USDA Natural Resources Conservation Service (NRCS) National Soil Survey Center, Lincoln, Nebraska. David Lindbo is director of Soil Science Division, USDA NRCS, Washington, DC. Diane Stott is a national soil health specialist for USDA NRCS Soil Health Division, Lafayette, Indiana. Phillip R. Owens is a research leader for USDA Agricultural Research Service (ARS) Dale Bumpers Small Farms Research Center, Booneville, Arkansas. 
Resources Conservation Service (NRCS) soil survey characterization database, found that a $1 \%$ increase in SOM can result in a $2 \%$ to $>5 \%$ increase in AWHC, depending on texture. Using different organic materials and various types of mineral soils, SOM was shown to increase the available water in sandy soils and, to a lesser extent, in heavy soils (Bouyoucos 1938; Rawls et al. 2003). Rawls et al. (2003), using soils in the USDA NRCS soil survey characterization database, found that the effect of change in organic carbon (OC) content on soil water retention at $-1,500$ and $-33 \mathrm{kPa}$ depended on the proportion of sand and clay and the amount of OC present in the soil. They showed that an increase in SOM led to an increase in water retention in sandy soils and to a decrease in fine textured soils. Rawls et al. (2003) postulated that for fine textured soils, the increase in SOM decreases the bulk density, improving soil structure and aggregation, thus affecting more the water retention at water contents closer to field capacity than wilting point. In addition, SOM can modify the availability of adsorption sites of clay minerals to water (Cristensen 1992, 1996). Thus, the combination of SOM amount with soil texture affects the "bound water" held in soil matrix either via electrostatic forces at adsorption sites and/ or surface tension (capillary forces) in soil pores (Schroeder 1984). In rangeland systems, litter and SOM in O horizons were shown to have a water-holding capacity that could intercept rainfall before it reached the soil mineral surface (Naeth et al. 1991). Emerson and McGarry (2003) found that as percentage $\mathrm{C}$ increased, the rate of pore formation $(\leq 30$ $\mu \mathrm{m}$ in diameter) increased, which was $50 \%$ greater for a sandy soil than for a silty soil. This increase was attributed to differences in the soil microbiology (a fungi-dominated versus a bacteria-dominated system). Bauer and Black (1992) found no change in the AWHC in coarse and moderately coarse soils with increases in OC concentrations, and found decreases in AWHC with increases in OC in medium and fine textured soils. In about 60 surface samples consisting of three texture groups (sands, silt loams, and silty clay loams), Hudson (1994) showed that as SOM increased from $0.5 \%$ to $3 \%$, the AWHC of the soil more than doubled in all three texture groups. Increases in AWHC of up to $10 \%$ (on per weight basis) per unit increase in SOM have been reported for sandy loam soils (Salter and Haworth 1961). Stevenson
(1994) reported that SOM alone (i.e., not incorporated or mixed with soil) can hold up to 20 times its weight in water. However, he did state that SOM may not contribute to AWHC, except in sandy soils.

The majority of the research data suggests that SOM (i.e., fully decomposed organic matter that is incorporated in soils) can hold water between one and five times its weight (Hudson 1994; Olness and Archer 2005). The very wide range of evaluations and estimates altogether raises two questions: (1) what is the real contribution of SOM to AWHC, and (2) what are the major factors contributing to the relationship between SOM and AWHC. To answer these questions, we addressed the relationships between SOM and AWHC first from the theoretical viewpoint based on underlying physical soil-SOM principles and second from the empirical viewpoint based on data.

The major hypotheses of this study are that (1) the contribution of SOM to AWHC is both direct and indirect, and (2) the contribution of SOM to AWHC is complex and depends on the interactions among several soil properties, including the amount of SOM, bulk density, texture, and structure.

\section{Materials and Methods}

Data Sources and Calculations. The National Cooperative Soil Survey (NCSS) Soil Characterization Database at the USDA NRCS National Soil Survey Center in Lincoln, Nebraska, was used for this study. Soil properties in this database are determined through standard methods in the Soil Survey Laboratory Methods Manual (Soil Survey Staff 2014). Properties used from the database were percentage sand (2 to $0.05 \mathrm{~mm})$, silt $(0.05$ to $0.002 \mathrm{~mm})$, and clay $(<0.002 \mathrm{~mm})$ determined by the pipet and sieve analysis method; OC content determined via acid-dichromate digestion (after 2000, method was no longer used); total $\mathrm{C}$ determined by high-temperature combustion; bulk density measured at water retention of $-33 \mathrm{kPa}$ determined on sarancoated soil clods; water contents at -10 and $-33 \mathrm{kPa}$ tensions measured on the same clod; water retention at $-1,500 \mathrm{kPa}$ determined on $<2 \mathrm{~mm}$ sieved soil; and calcium carbonate $\left(\mathrm{CaCO}_{3}\right)$ equivalent determined by acid digestion in a closed vessel measured via manometer (to correct for $\mathrm{CaCO}_{3}-\mathrm{C}$ ). All determinations, except bulk density and water retention, were made on air-dried $\left(30^{\circ} \mathrm{C}\right.$ to $\left.35^{\circ} \mathrm{C}\right)$, crushed, and sieved $(<2$ $\mathrm{mm}$ ) soil samples. Data are reported on an oven-dry basis. Data are also reported by soil horizon (e.g., Ap, Bt1). Pedon data include a soil taxonomic classification based on the profile description and the quantitative data.

Total C was converted to soil organic carbon (SOC) as the difference between total $\mathrm{C}$ and $\mathrm{CaCO}_{3}-\mathrm{C}$ (Burt 2011). The SOM content was calculated from SOC using the Van Bemmelen Factor of 1.724 (SOC $\% \times 1.724)$, which is a standard factor used in soil survey (Burt 2011). Water content on a weight basis was multiplied by the bulk density at $-33 \mathrm{kPa}$ tensions to convert gravimetric water content $\left(\mathrm{g} \mathrm{cm}^{-3}\right)$ to a volumetric water content (\%). Available water-holding capacity was then calculated as the difference between the volumetric water retained at $-33 \mathrm{kPa}(-10$ $\mathrm{kPa}$ for sandy soils) and $-1,500 \mathrm{kPa}$ tensions.

Soil particle density and porosity were calculated for all layers in the data set. Soil particle density (Dp) was calculated using a standard mineral particle density of $2.65 \mathrm{~g}$ $\mathrm{cm}^{-3}$ (quartz) and equation 1 :

$\mathrm{Dp}=100 /\left\{\left[\mathrm{SOM} / \mathrm{Dp}_{\mathrm{som}}\right]+[(100-\right.$ $\mathrm{SOM} / 2.65]\}$,

where SOM = organic matter content of the soil (\%); and $\mathrm{Dp}_{\text {som }}=$ particle density of SOM, which was calculated from Rühlmann et al. (2006) using equation 2 :

$\mathrm{Dp}_{\text {som }}=1.127+0.373 \times \mathrm{SOM} / 100$.

The particle density of SOM ranges from 1 to $1.5 \mathrm{~g} \mathrm{~cm}^{-3}$. Total porosity was calculated as equation 3 :

Porosity $=\left[1-\left(\mathrm{Db}_{33} \div \mathrm{Dp}\right)\right] \times 100$,

where $\mathrm{Db}_{33}=$ bulk density at $-33 \mathrm{kPa}$ water content $\left(\mathrm{g} \mathrm{cm}^{-3}\right)$.

Data Sets and Analyses. Dispersive soils with a sodium $(\mathrm{Na})$ adsorption ratio (SAR) $>1$ were excluded from the data set. The $\mathrm{SAR}>1$ is an indicator of a $\mathrm{Na}$ amount that can cause soil structural problems or dispersion. Soil samples with andic soil properties were removed from the database. Any soil in an Andisol order, or any layer with a textural modifier of medial, ashy, or hydrous or that has a family particle-size class containing medial, ashy, or hydrous, was removed from the data set. Andisols formed in volcanic materials and have unique chemical 
properties (anion retention) and physical properties (low particle density and low bulk density) that differ greatly from those of other soils. We also removed inconsistent data, such as negative values for $-33 \mathrm{kPa}$ minus $-1,500 \mathrm{kPa}$ water, from the data set. The location of all pedons used in the study are presented in figure 1.

The data set was subset for each analysis. For general analysis of SOM versus AWHC, only $\mathrm{A}$ and $\mathrm{O}$ horizons were used from pedons with a smectitic, kaolinitic, mixed, or siliceous taxonomic mineralogy class or in the Histosols order. The selected taxonomic mineralogy classes are the most common for agricultural soils and comprise more than 95\% of the contiguous United States (Soil Survey Staff 2017). Mineralogy classes are not assigned to soils in the Histosols order (Soil Survey Staff 1999).

For the effects of particle size and other soil properties on AWHC, only A horizons from pedons with mixed mineralogy that have SOM contents $\leq 8 \%$ were used. For the effects of texture on AWHC versus SOM, the above data set was further stratified by texture class, and only the sandy (i.e., sands, fine sands, and loamy sands), silt loam, and silty clay loam textures were used. These three texture groups represent low, moderate, and high ranges in clay content. Textures were all from soils with a mixed taxonomic mineralogy class so that variability in AWHC due to differences in clay mineralogy was reduced.

For the effects of mineralogy on AWHC versus SOM, only A horizons from pedons with total clay $\geq 40 \%$ and SOM contents $\leq 8 \%$ were selected from the database. This sub data set was further stratified by taxonomic mineralogy class, and only the kaolinitic, smectitic, and mixed mineralogy strata were used.

Pearson's correlations and first, second, and third order linear regression analyses were conducted to determine the relationship between AWHC and soil properties. The coefficient of determination $\left(r^{2}\right)$ was used as a measure of the proportion of variance that can be explained by a predicted outcome. The root mean square error (RMSE) was used to represent the standard deviation about the regression line. The statistical analyses were performed in Sigma Plot 12.0 and SYSAT13 (Systat Software, Inc., San Jose, California). Correlations were considered significant at $p=0.05$.

\section{Figure 1}

Location of pedons from the Kellogg Soil Survey Laboratory used in this study.

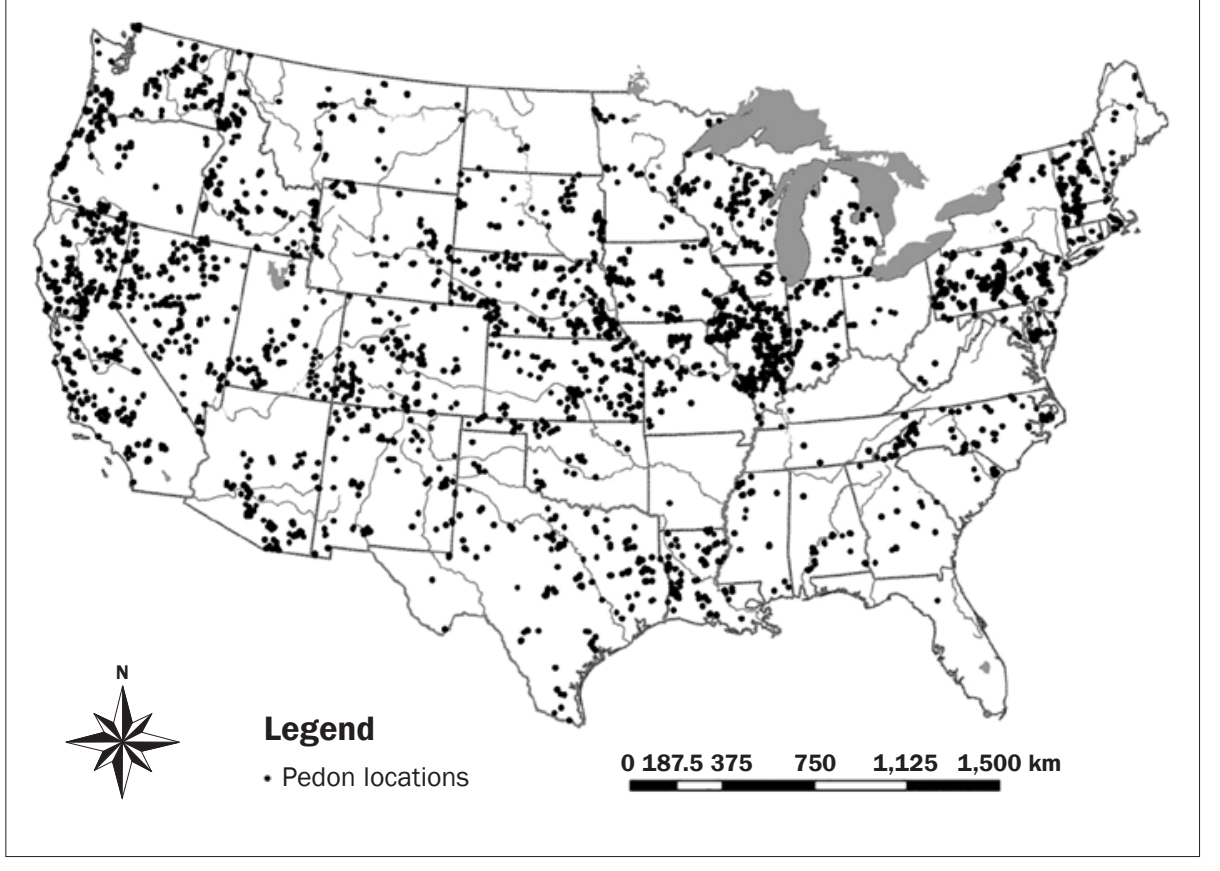

\section{Results and Discussion}

Theoretical Calculations: Soil Organic Matter and Available Water-Holding Capacity. The contribution of water held by SOM to AWHC can be calculated based on knowledge of the physical properties of SOM obtained from referenced publications (table 1). The two key OM properties needed are particle density and bulk density (table 1). Organic matter (and its porosity) is combined with the mineral soil (and its porosity). Taking this approach allows the soil to expand to accommodate the OM, which is the most likely scenario if OM is going to contribute water to AWHC. For each 1\% increase in OM, a resultant soil bulk density is calculated, incorporating both changes in the soil particle density (Dp) and OM particle density $\left(\mathrm{Dp}_{\mathrm{om}}\right)$ (table 1$)$. Increases in OM cause a decrease in the soil bulk density because the OM particle density and bulk density are much lower than those for a purely mineral soil. The increasing soil porosity or pore volume attributed to OM is calculated from the change in the soil bulk density, which is mathematically related to porosity. Based on these calculations, total soil porosity increases to approximately $14 \%(0.14$ on a volume fraction basis) as the $\mathrm{OM}$ increases to $8 \%$. Thus, the contribution of water held by SOM to AWHC would be constrained to the $14 \%$ porosity added by OM (table 1 ). The initial AWHC for the soil in table 1 is
0.20 (volume fraction) or 20\% (table 2) and has the potential to increase by $70 \%$ when $\mathrm{OM}$ increases to $8 \%$. As OM increases to $100 \%$, soil porosity increases to $85 \%$, which would vastly increase the capacity of the soil to hold water, but not necessarily all in the AWHC range (table 2).

The theoretical calculations derived here show that the potential AWHC increase (on a volumetric basis) from a unit increase in OM (\% weight) is about 1.5 to 1.7 times its weight for the $0 \%$ to $8 \%$ OM range (table 1). This potential increase in AWHC assumes that the entire increase in soil porosity from incremental $\mathrm{OM}$ additions holds water in the AWHC range, which is unlikely. The increase in AWHC is independently supported by the analysis of the empirical data in this study, which shows an average increase in AWHC of up to 1.5 times the OM's weight for the $0 \%$ to $8 \%$ range in OM.

Calculation of AWHC in terms of weight of water for an acre furrow slice is presented in table 2 . The soil conditions calculated in table 1 are continued into table 2. Initial water retentions at $-1,500 \mathrm{kPa}$ and $-33 \mathrm{kPa}$ are 0.13 and 0.33 (volume fraction). Soil porosity calculated in table 1 is carried forward to calculate water contents at $-1,500$ $\mathrm{kPa}$ and $-33 \mathrm{kPa}$ tensions. Total AWHC for the whole soil is calculated. It is assumed that all of the porosity associated with OM contributes water to AWHC. Volume of water is 
Table 1

Soil organic matter (SOM) contribution to soil porosity and available water-holding capacity (AWHC) is calculated based on known physical properties of OM. Initial soil conditions have no SOM, a bulk density of $1.5 \mathrm{~g} \mathrm{~cm}^{-3}$, and a mineral particle density of $2.65 \mathrm{~g} \mathrm{~cm}^{-3}$. The SOM is assumed to be well decomposed, as in humus, such that the influence on AWHC is long term.

\begin{tabular}{|c|c|c|c|c|c|c|}
\hline \multirow[b]{2}{*}{ OM (\% weight) } & \multirow[b]{2}{*}{$\begin{array}{l}\text { OM particle } \\
\text { density }\left(\mathrm{g} \mathrm{cm}^{-3}\right)^{*}\end{array}$} & \multirow[b]{2}{*}{$\begin{array}{l}\text { Soil particle } \\
\text { density }\left(\mathrm{g} \mathrm{cm}^{-3}\right) \dagger\end{array}$} & \multirow[b]{2}{*}{$\begin{array}{l}\text { Soil bulk } \\
\text { density }\left(\mathrm{g} \mathrm{cm}^{-3}\right) \ddagger\end{array}$} & \multirow[b]{2}{*}{$\begin{array}{l}\text { Soil porosity } \\
\text { (vol fract)§ }\end{array}$} & \multicolumn{2}{|c|}{ Potential AWHC increase } \\
\hline & & & & & $\begin{array}{l}\text { OM porosity } \\
\text { (vol fract) II }\end{array}$ & $\begin{array}{l}1.5 \times 0 \mathrm{OM} \mathrm{wt} \\
\text { (vol fract) }\end{array}$ \\
\hline 0 & - & 2.65 & 1.50 & 0.43 & - & - \\
\hline 1 & 1.13 & 2.61 & 1.42 & 0.46 & 0.02 & 0.02 \\
\hline 2 & 1.13 & 2.58 & 1.34 & 0.48 & 0.04 & 0.04 \\
\hline 3 & 1.14 & 2.55 & 1.28 & 0.50 & 0.05 & 0.06 \\
\hline 4 & 1.14 & 2.52 & 1.22 & 0.52 & 0.08 & 0.07 \\
\hline 5 & 1.15 & 2.49 & 1.16 & 0.53 & 0.10 & 0.09 \\
\hline 6 & 1.15 & 2.46 & 1.11 & 0.55 & 0.11 & 0.10 \\
\hline 7 & 1.15 & 2.43 & 1.07 & 0.56 & 0.13 & 0.11 \\
\hline 8 & 1.16 & 2.40 & 1.02 & 0.57 & 0.14 & 0.12 \\
\hline 80 & 1.43 & 1.57 & 0.27 & 0.83 & 0.40 & 0.32 \\
\hline 100 & 1.50 & 1.50 & 0.22 & 0.85 & 0.41 & 0.33 \\
\hline
\end{tabular}

*OM particle density $\left(\mathrm{Dp}_{\mathrm{om}}\right)=1.127+0.373 \times \mathrm{OM} \div 100$ (Rühlmann et al. 2006).

†Soil particle density $(\mathrm{Dp})=100 \div\left[\mathrm{SOM} \div \mathrm{Dp}_{\mathrm{om}}+(100-\mathrm{SOM}) \div 2.65\right]$.

$\ddagger$ Soil bulk density $(\mathrm{Db})=100 \div\left[\mathrm{OM} \div \mathrm{Db}_{\mathrm{om}}+(100-\mathrm{OM}) \div 1.50\right] ; \mathrm{Db}_{\mathrm{om}}=$ bulk density of organic matter, a value of $0.22 \mathrm{~g} \mathrm{~cm}^{-3}$ was used (Rawls et al. 1983).

$\S$ Soil porosity $=(1-\mathrm{Db} \div \mathrm{Dp}) \div 100$.

II OM porosity $=$ Soil porosity - initial soil porosity of 0.43 .

Table 2

Calculation of available water-holding capacity (AWHC) for an acre furrow slice (AFS). An AFS is determined by multiplying the number of square feet in an acre $(43,560)$ by a depth of $0.49 \mathrm{ft}(15 \mathrm{~cm}$ furrow slice $[5.9 \mathrm{in}] \div 30.48 \mathrm{~cm}[12 \mathrm{in}]=0.49 \mathrm{ft})$.

\begin{tabular}{|c|c|c|c|c|c|}
\hline \multirow[b]{2}{*}{ OM (\% weight) } & \multirow[b]{2}{*}{$\begin{array}{l}1,500 \mathrm{kPa} \\
\text { (vol fract) }\end{array}$} & \multirow[b]{2}{*}{$\begin{array}{l}33 \mathrm{kPa} \\
\text { (vol fract) }\end{array}$} & \multirow[b]{2}{*}{$\begin{array}{l}\text { AWHC } \\
\text { (vol fract) }\end{array}$} & \multicolumn{2}{|l|}{ AWHC for AFS* } \\
\hline & & & & Total water (gal)† & Water in OM (gal)‡ \\
\hline 0 & 0.13 & 0.330 & 0.200 & $32,587(123,354)$ & 0 \\
\hline 1 & 0.13 & 0.354 & 0.224 & $36,487(138,117)$ & $3,900(14,762)$ \\
\hline 2 & 0.13 & 0.375 & 0.245 & $39,993(151,389)$ & $7,406(28,034)$ \\
\hline 3 & 0.13 & 0.395 & 0.265 & $43,163(163,391)$ & $10,577(40,037)$ \\
\hline 4 & 0.13 & 0.413 & 0.283 & $46,046(174,303)$ & $13,459(50,949)$ \\
\hline 5 & 0.13 & 0.429 & 0.299 & $48,680(184,272)$ & $16,093(60,918)$ \\
\hline 6 & 0.13 & 0.444 & 0.314 & $51,096(193,420)$ & $18,509(70,066)$ \\
\hline 7 & 0.13 & 0.457 & 0.327 & $53,322(201,847)$ & $20,736(78,493)$ \\
\hline 8 & 0.13 & 0.470 & 0.340 & $55,381(209,640)$ & $22,794(86,286)$ \\
\hline 80 & 0.13 & 0.727 & 0.597 & $97,293(368,295)$ & $64,706(244,940)$ \\
\hline 100 & 0.13 & 0.729 & 0.599 & $97,658(369,675)$ & $97,658(369,675)$ \\
\hline
\end{tabular}

* Liters in parentheses.

†Total AWHC in AFS (gal) $=(62.428 \div 2 \times$ AWHC $) \times 8.345 \div 43,560$; cubic foot of water $=62.428 \mathrm{ft}^{3}$; gallon of water $=8.345 \mathrm{lb} ;$ ac $=43,560 \mathrm{ft}^{2}$.

$\neq$ Water in soil organic matter $(\mathrm{OM})(\mathrm{gal})=$ total $\mathrm{AWHC}$ in AFS $\times 3.78541$.

then converted to weight of water, resulting in an average increase of $10,800 \mathrm{~L}$ of water for each additional $1 \%$ increase in SOM (up to $8 \% \mathrm{OM}$ ) for an acre furrow slice (table 2 , figure 2). Recent suggestions that SOM is able to hold water up to 10 to 20 times its weight are physically unattainable for average soil conditions (figure 3 ). In order to satisfy these conditions at about 5\% SOM $(20 \times \%$ SOM scenario) and 11\% SOM (10 $\times \%$ SOM scenario), the entire unit volume of soil has to be occupied by water with no room for the mineral soil. Thus, for any additional $1 \%$ increase in SOM above 5\% and $11 \%$ thresholds, additional volume above the unit volume is needed. In the extremely unlikely case scenario of $100 \%$ SOM, the unit volume will have to increase to 2.2 units $(10 \times \%$ SOM scenario $)$ and 4.4 units $(20$ $\times \%$ SOM scenario) in order to accommodate the amount of water. These calculations show the physical conditions that limit the ability of SOM to contribute to AWHC. 
It is critical to emphasize that some of the assumptions made for these calculations are conservative in that they may even overestimate the contribution of SOM to AWHC. First, the volume fraction of SOM contribution to AWHC for the $-1,500 \mathrm{kPa}$ (wilting point) is held constant $(0.13)$ for the entire range (0 to 100$)$ of SOM. In other words, all AWHC increase due to SOM increase is assigned to the $-33 \mathrm{kPa}$ (field capacity range). This may not be true, as demonstrated by others (Bauer and Black 1992); an increase in SOM would not necessarily contribute all its water to AWHC pore range. Second, the drainable porosity on volume fraction, which is calculated as the difference between soil porosity (table 1) and field capacity at -33 $\mathrm{kPa}$ (table 2), is also being held constant at 0.104 . This assumption is also not always true as the drainable porosity may increase as the SOM increases but at the expense of AWHC porosity range. These assumptions do not capture the interaction between SOM and soil structure that could lead to changes in the pore size distribution. These changes may not always be associated with AWHC pore size range. The assumptions maximize the contribution of SOM to AWHC range. Even with these assumptions in place, the theoretical calculations show that $1 \%$ SOM increase can only add close to $10,800 \mathrm{~L}$ of water under average soil conditions. The limited data $(n=58)$ from the Kellog Soil Survey Laboratory (KSSL) database support these calculations as well by showing that, on average, AWHC for ranges of SOM between $30 \%$ and $50 \%$ occupies between 0.52 and 0.62 of volume fraction.

Empirical Relationships from Measured Soil Data. Available water-holding capacity was significantly correlated to the total silt content $(r=0.56 ; n=4,783)$. The slope of the curve was greater at lower silt contents (starting at $0 \%$ and increasing to $30 \%$ ), leveled out somewhat, and then increased again after $60 \%$ silt (figure $4 a$ ). Total silt, $(\text { silt })^{2}$, and (silt) ${ }^{3}$ were able to explain only $32 \%$ of the variability in AWHC (figure 4a). Siltsized particles are generally associated with pores 0.2 to $10 \mu \mathrm{m}$ in diameter, which hold water between -33 and $-1,500 \mathrm{kPa}$ tensions (Soil Survey Division Staff 1993; Rawls et al. 1983). Total sand had a weaker and negative correlation with AWHC $(r=-0.47$; $n=4,783)$. As the sand content increased, AWHC followed a decreasing trend. Total clay had almost no correlation to AWHC $(r=$
Figure 2

Relationship between soil organic matter (SOM; \% weight) and the amount of water (AWC; weight) for $0 \%$ to $8 \%$ SOM, based on empirical data suggesting that $1 \mathrm{~g}$ SOM holds up to $1.5 \mathrm{~g}$ water. Numbers above the curve represent liters while numbers below the curve represent gallons.

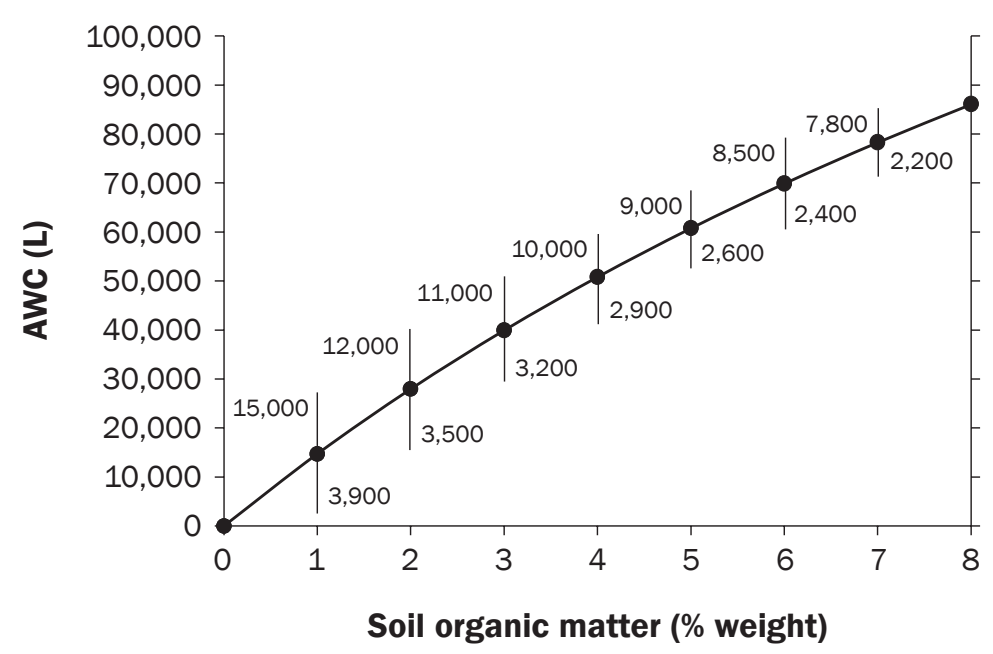

\section{Figure 3}

Theoretical relationship between soil organic matter (SOM; \% weight) and volumetric water content based on empirical data suggesting that $1 \mathrm{~g}$ SOM holds up to $1.5 \mathrm{~g}$ water, and two scenarios suggesting $1 \mathrm{~g}$ SOM holds up to 10 and $20 \mathrm{~g}$ water. The red line represents the unit volume for $1 \mathrm{~cm}^{3}$.

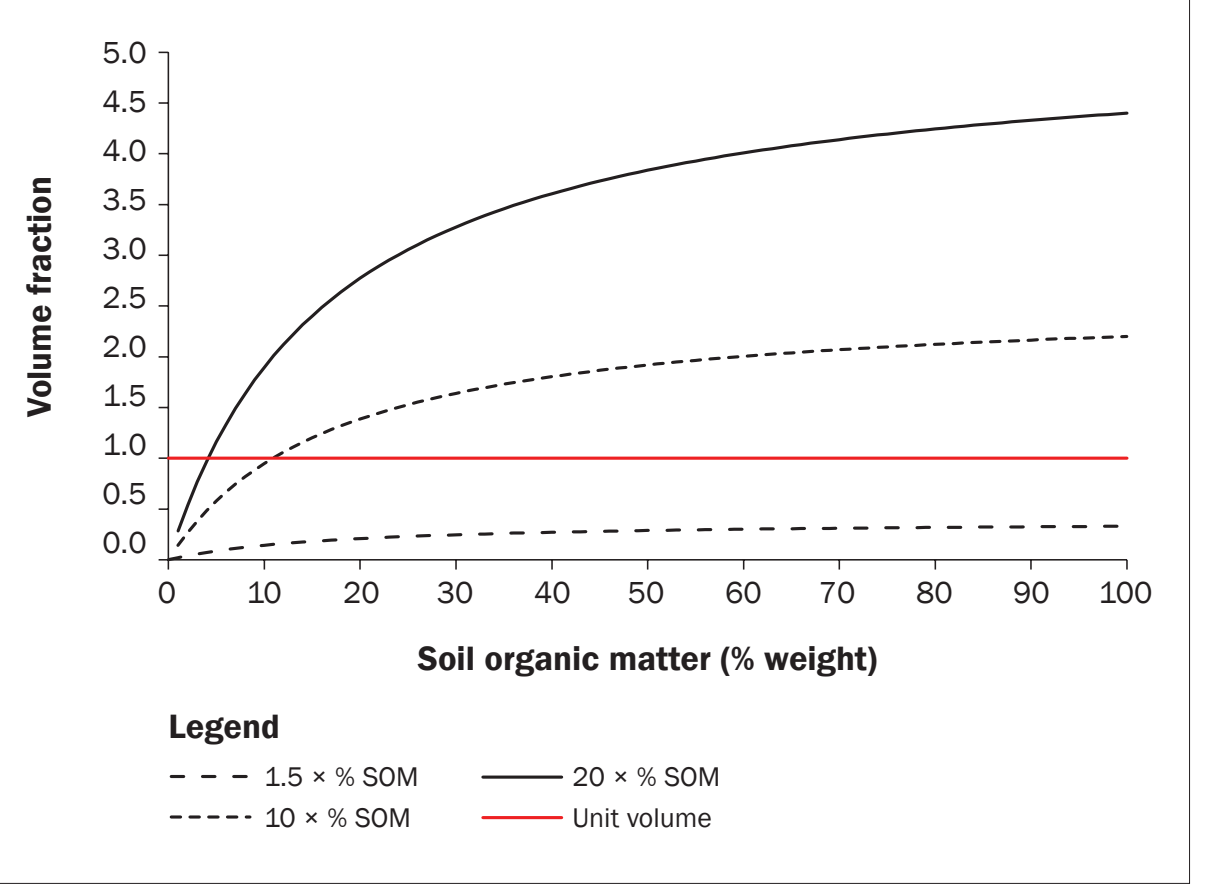

$0.06 ; n=4,783)$, and the relationship showed an increase in AWHC with clay content followed by a decrease as clay content increased. The total clay is most notably associated with the water contents held at the wilting point (or $-1,500 \mathrm{kPa}$ matric potential) (Burt 2011).
As expected, in our study, total clay content was highly correlated with $-1,500 \mathrm{kPa}$ water contents $(r=0.87 ; n=4,783)$. Clay particles produce clay-sized pores $(<0.2 \mu \mathrm{m})$ that mostly contribute to water (tightly bound to clay surface and other organic colloids) 
retained at the wilting point (or $-1,500 \mathrm{kPa}$ matric potential), especially for soils with more than 40\% clay (Soil Survey Staff 2014). Also, at $-1,500 \mathrm{kPa}$ tensions, water is in thin films covering surfaces; therefore, it is likely related to the surface area of clay particles (Brady and Weil 1999; Schroeder 1984; Jury et al. 1991).

Clay content is generally closely associated with silt content. In the present study, the total silt plus total clay was moderately correlated to AWHC $(r=0.47 ; n=4,783)$ (figure $4 \mathrm{~b})$. Total silt + clay and (silt + clay) ${ }^{2}$ only explained $24 \%$ of the variability in AWHC (figure 4b), which was a decrease compared to total silt alone. Emerson (1995) also indicated that the silt/clay matrix holds a constant amount of water.

Bulk Density and Available WaterHolding Capacity. Available water-holding capacity had a weak and negative correlation to bulk density $(r=-0.34 ; n=4,783)$. As the bulk density decreased, AWHC generally increased, but was highly variable. This indicates that AWHC is controlled not only by the soil constituents, such as mineral and organic particles, but also by other factors, including their spatial arrangement and packing (Schroeder 1984). The higher the bulk density, the less pore space there is to potentially hold water. As the bulk density increases, the larger pores are lost first, which influences the gravitational water content (water held between saturation and field capacity). A decrease in soil bulk density can be caused by an increase of the SOM content (Brady and Weil 1999) through two processes. First, SOM has a lower particle density than mineral particles, and this by itself reduces the bulk density. Secondly, SOM can change the quantity and structure of pores due to SOM porosity itself and enhancement of soil aggregation and structure (Jamison and Kroth 1958; Bauer and Black 1992; Olness and Archer 2005). Other factors such as colloidal fillings, specific charge, and polarity also affect moisture retention (Hudson 1994). Increases in SOM generally increase the soil porosity (figure 5). Despite these processes, in the KSSL data set, SOM only explains 30\% of the variability in the porosity (figure 5), and its contribution was highly uncertain $($ RMSE $=6 \%)$. This suggests that water held by SOM is highly variable from soil to soil. On average, a 1\% increase in SOM resulted in a $2.3 \%$ increase in soil total porosity (figure $5)$. For soil porosity to increase, the min-

\section{Figure 4}

Soil available water-holding capacity (AWHC) versus (a) total soil silt and (b) total soil silt and clay combined.

(a)

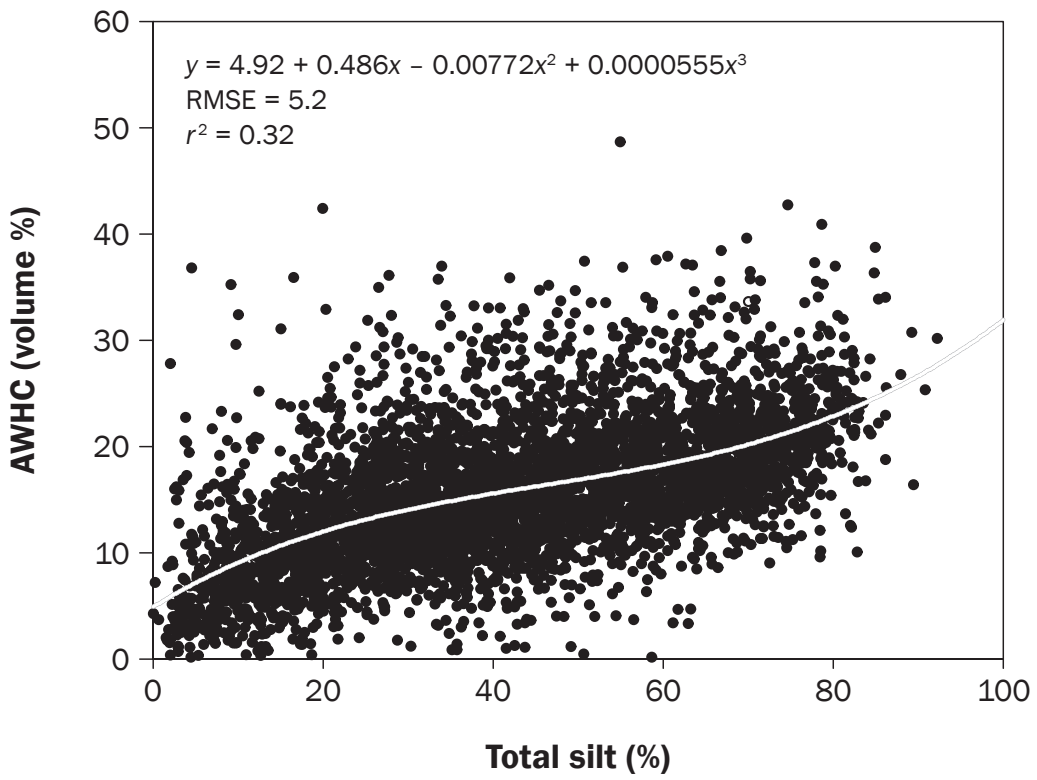

(b)

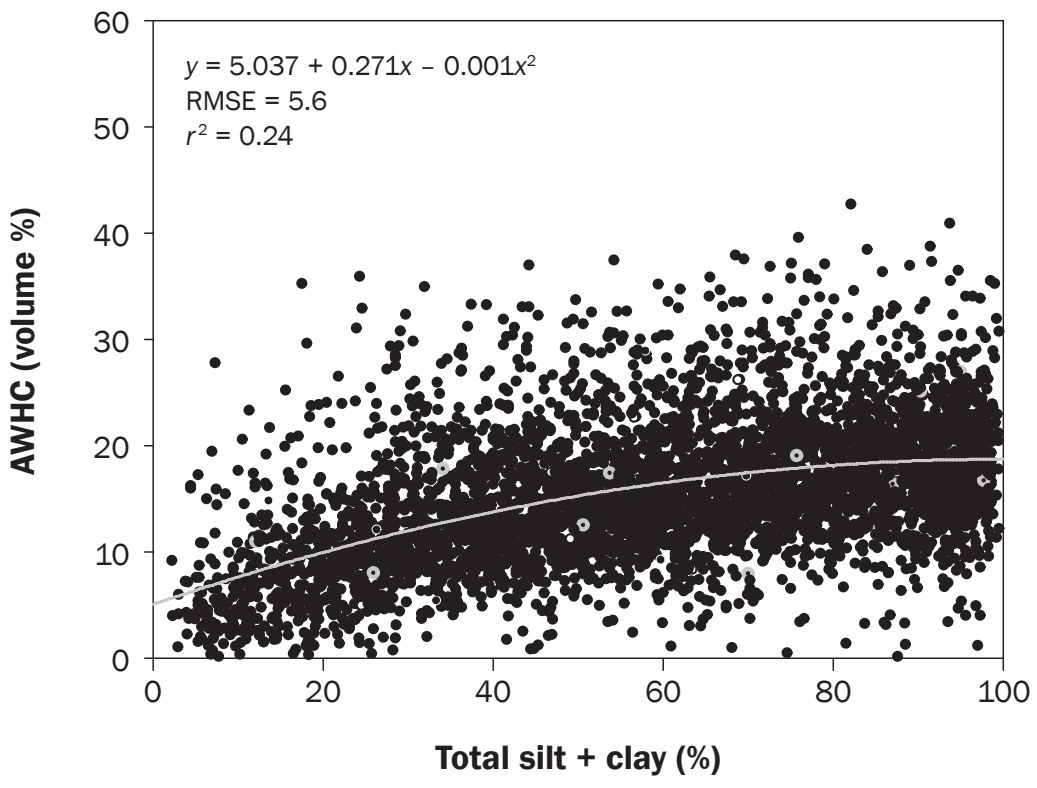

eral material must expand to accommodate the additional pore space. The high degree of variability in figure 5 indicates that soil porosity does not always increase with every increase in SOM. Emerson and McGarry (2003) found that negatively charged SOM does not necessarily increase porosity. Also, if the soil does not expand, then the increase in SOM would occupy the pore space that is already present, and the soil would become denser. However, there would be a limit to the amount of SOM that could be accommodated without the soil expanding. In the scenario outlined in table 1 , the soil expands to accommodate the additional SOM and associated porosity, and, like the previous two assumptions made for the theoretical calculations (see "Theoretical Calculations: Soil Organic Matter and Available WaterHolding Capacity"), allows the maximum contribution of SOM to AWHC range. 


\section{Figure 5}

Relationship between soil organic matter and total soil porosity.

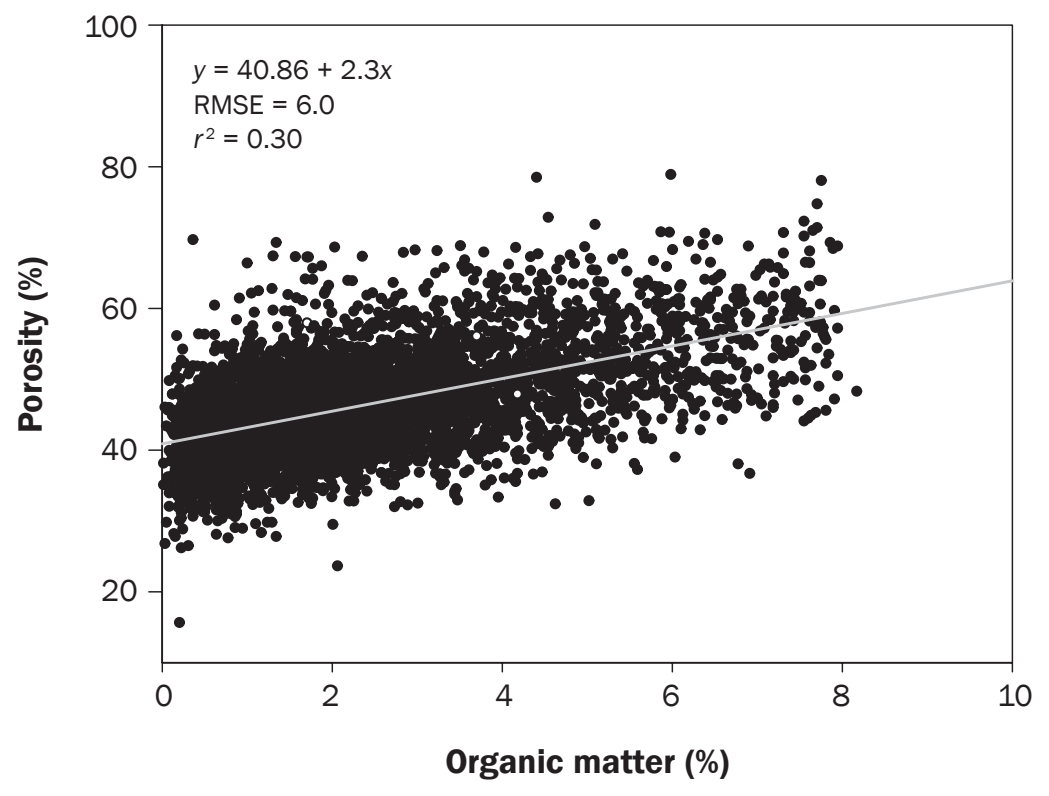

Increases in porosity can have positive effects on the physical condition of soils, such as improved infiltration rates and soil structure (Brady and Weil 1999; Schroeder 1984; Jury et al. 1991), that were not directly evaluated in the present study. In turn, these effects can decrease runoff by allowing precipitation to move downward into the soil profile and recharge the available water (Chandrasoma et al. 2016; Packer et al. 1992).

Organic Matter and Available WaterHolding Capacity. Available water-holding capacity was weakly correlated to the SOM content within the $0 \%$ to $8 \%$ range $(r=0.27$; $n=4,783)$. Within this range, the SOM was only able to explain $7.6 \%$ of the variation in AWHC (figure 6a). On average, a 1\% increase in SOM resulted in a $1 \%$ volume increase in AWHC in the $0 \%$ to $8 \%$ SOM range (figure 6a). If SOM increases from $0 \%$ to $3 \%$, AWHC would increase by $3 \%$. However, the large deviation $($ RMSE $=6.2 \%$; figure $6 a$ ) indicates a high degree of variability for the influence of SOM on AWHC. This generality indicates that SOM alone may or may not contribute substantially to AWHC. As discussed above, in the scenario where the soil does not expand with increases in SOM, AWHC is unlikely to increase (given there is no additional pore space) and may even decrease. Also, since AWHC is the difference between water held at field capacity and water held at wilting point, a unit increase in SOM concentration can cause essentially equal increases in water contents at both field capacity and wilting point, resulting in no change in AWHC (Bouyoucos 1938; Bauer and Black 1992; Stevenson 1994). This might explain, in part, the high variability in AWHC among soils with increases in SOM. The variability is critical, especially when causational statements about the impact of SOM on AWHC have to be made with complete confidence. Unfortunately, the KSSL data set does not contain replications of the same soil under different conditions or management systems with different levels of SOM that would establish direct measurable cause-effect relationships between SOM and AWHC under different crops and/or management scenarios.

Our results $(1 \%$ increase in SOM can increase AWHC by $1 \%$ ) are in the lower end of the range reported by others. Hudson (1994) reported that a unit increase in SOM (\% weight) increases AWHC by $2.2 \%$ (sands) to $3.8 \%$ (silt clay loams) on a volume basis for 60 surface soils consisting of three texture groups. Other research shows that a $1 \%$ increase in SOM (on weight basis) can increase the soil water content within the AWHC range up to $5 \%$ (by volume), depending on soil texture (Emerson et al. 1994; Emerson 1995; Hamblin and Davies 1977; Russell and Shearer 1964; Barrow 1969; Russell et al. 1952; Rose 1991).

Emerson (1995) suggested that in soils with $<7 \%$ OC, SOM may not contribute to water retention because of the type of SOM present (or lack of polysaccharide gels). In the present study, SOM values varied from $0 \%$ to $8 \%$, values that are most common under cultivated field conditions. More than $90 \%$ of the values from the database were within the $0.5 \%$ to $7 \%$ SOM range, which covers most arable, pasture, and forest lands.

Because there was a limited number of soils with SOM values ranging from $8 \%$ to $100 \%$, we could look closely at the relationship between SOM and AWHC along the higher end of the SOM range so as to better evaluate the role of SOM, especially its AWHC capabilities. High SOM contents are found mostly in drained organic cultivated soils, wetlands, marshlands, and bogs/peats.

In high SOM soils, the SOM content was correlated to AWHC $(r=0.62 ; n=509)$ and the degree of variation ( $\mathrm{RMSE}=13.7 \%)$ was large (figure 6b). Soil organic matter content was able to explain about $39 \%$ of the variation in AWHC (figure 6b). However, a 1\% increase in SOM resulted, on average, in only a $0.45 \%$ volume increase in AWHC in these organic soils (figure $6 \mathrm{~b}$ ). In other words, the contribution of SOM to AWHC in organic soils was about half that of soils dominated by mineral material. This suggests that SOM in intimate association with mineral material has a greater influence on retaining water in the AWHC range than SOM in a high SOM soil. However, the average water-holding capacity of organic soils is greater than that of mineral soils (figures $6 \mathrm{a}$ and $6 \mathrm{~b}$ ).

Because of the changing nature of the soil matrix (mineral-dominated to organicmaterial-dominated surface horizons), the change in AWHC ranges from about $2.5 \%$ to $5 \%$ per $1 \%$ change in OC in soils containing less than $2.5 \%$ OC and less than $40 \%$ clay (Olness and Archer 2005). Studies have shown that a continuous increase of SOM could eventually lead to a proportionate decrease of soil mineral material, ultimately resulting in the separation of SOM from the mineral material (Olness and Archer 2005; Feustal and Byers 1936). These changes are associated with the change not only in pore space, but more importantly, in the pore space distribution and, as a result, AWHC.

Effect of Texture. The association of SOM and AWHC was evaluated on different texture groups - sandy, silt loams, and silty clay loams. In general, AWHC increased as SOM increased, but the relationship was highly variable (figure 7). Soil organic matter 


\section{Figure 6}

Soil available water-holding capacity (AWHC) versus soil organic matter (SOM) for (a) $0 \%$ to $8 \%$ range and (b) $0 \%$ to $100 \%$ range of SOM.

(a)

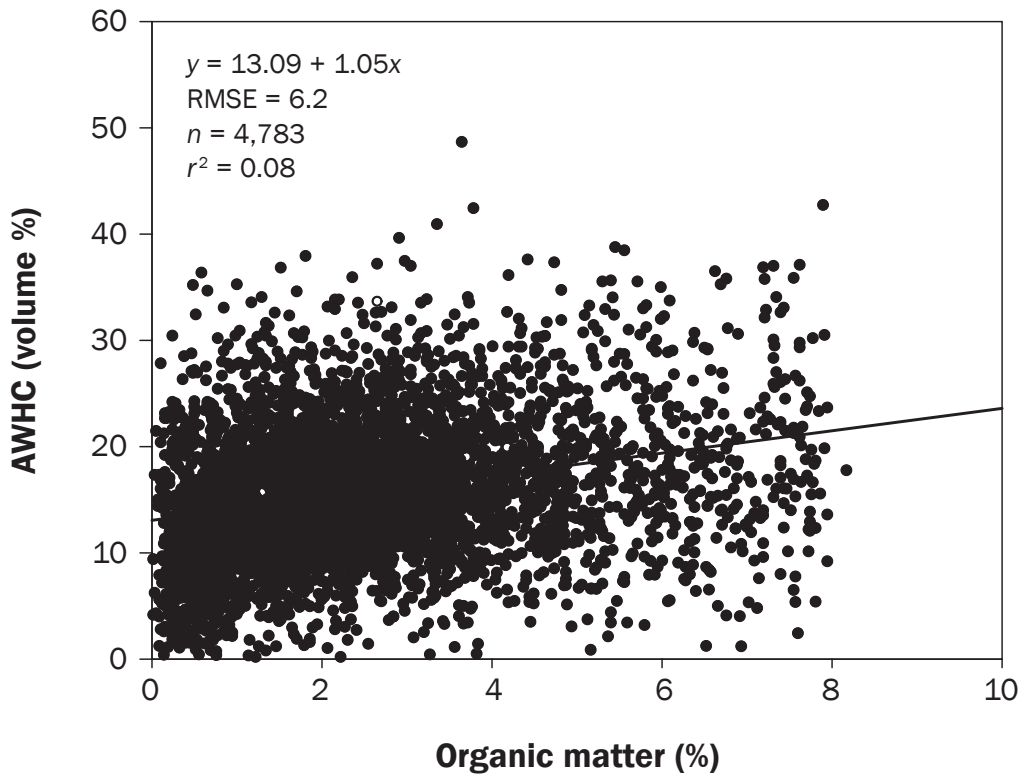

(b)

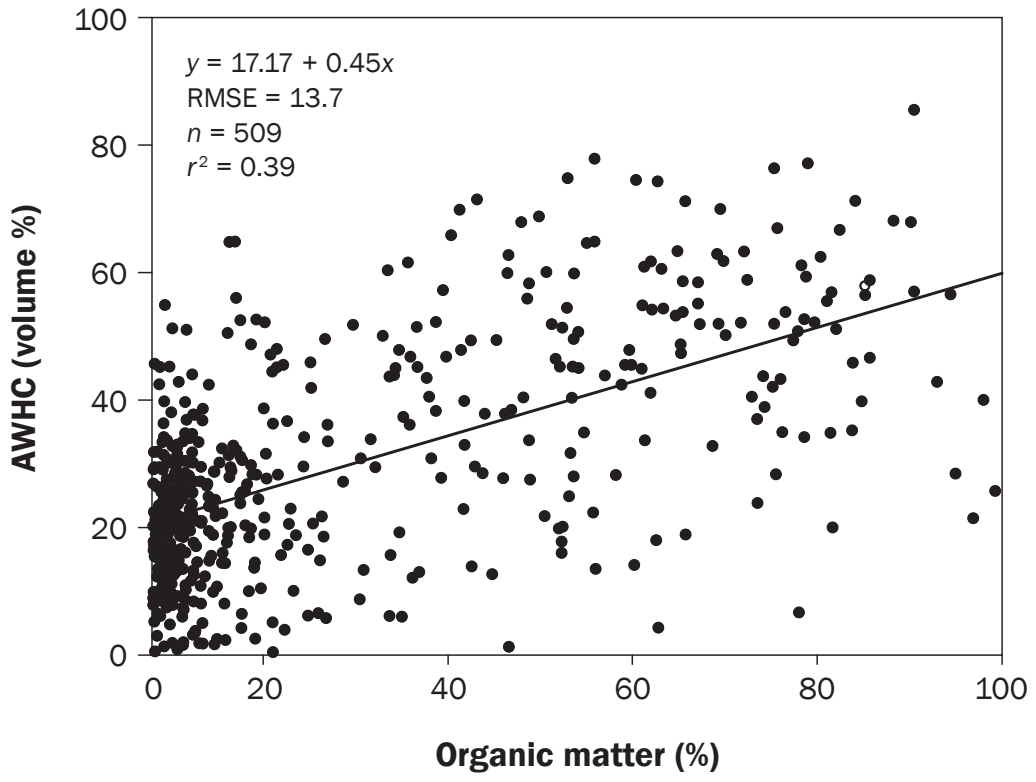

explained $13 \%$ of the variation in AWHC for sandy soils; it explained only $2 \%$ and $6 \%$ of the variability for the silt loams and clayey textures, respectively (figure 7). The magnitude of SOM contribution to AWHC was greatest for the sandy group compared to the silt loams and silt clay loam groups. On average, a $1 \%$ increase in SOM increased AWHC by $1.5 \%$ for the sandy textures, compared to $0.6 \%$ for the silt loam and silty clay loam textures (figure 7). Soil organic matter had
Other research points to the complex interactions between texture and SOM in relation to AWHC. For example, Rawls et al. (2003) showed that at low SOC contents, the sensitivity of water retention to changes in SOC is the highest at about 3\% and then decreases. For finer textured soils, they showed increases in SOC above 3\% to $5 \%$ that led to water retention decreases. Bauer and Black (1992) found results similar to ours (i.e., the effect of SOC on water retention was more pronounced in sandy soils compared to medium and finer textured soils). Similar findings were also reported by Rawls et al. (2003).

Effect of Clay Type. For clayey soil samples in the database ( $>40 \%$ clay), the effect of SOM on AWHC was evaluated on soils with two different dominant clay typeskaolinite (figure 8a) and smectite (figure $8 b$ ) - as well as mixed mineralogy (figure $8 c)$. The effect of SOM differed between clay mineral types. On average, a $1 \%$ increase in SOM (on weight basis) increased AWHC by only $0.23 \%$ (on volume basis) for soils with smectitic mineralogy, compared to $1.03 \%$ for soils with kaolinitic mineralogy (figures $8 \mathrm{a}$ and $8 \mathrm{~b}$ ). The addition of SOM had little effect on increasing AWHC in soils dominated by smectite clays. Soil organic matter explained only $0.7 \%$ of the variation in AWHC for soils dominated by smectite clays. For soils dominated by kaolinite clays, addition of SOM had a greater influence on AWHC, but was highly variable (RMSE = $5.7 \%)$. Soil organic matter explained $24 \%$ of the variation in AWHC for soils dominated by kaolinite clays. For the clays in the mixed mineralogy class (figure $8 \mathrm{c}$ ), the slope $(0.7)$ of the least squares line was, as expected, between that for soils dominated by smectite clays $(0.2)$ and those dominated by kaolinite clays (1.0). These results suggest that the clay mineral type does influence the effect of SOM on AWHC. The fact that humified SOM is intimately associated with, or firmly bound to, colloidal clay as organic coatings (Stevenson 1994) suggests that the structure and function of SOM would vary with the mineralogical composition (Cristensen 1992). Soils with smectite clays shrink and swell with changes in water content, and they have a higher cation-exchange capacity. These properties alter the effects of SOM on AWHC. Others have indicated that soils with higher exchange capacities can retain more $\mathrm{C}$ in their humus form and/or that it 


\section{Figure 7}

Soil available water-holding capacity (AWHC) versus soil organic matter range $0 \%$ to $8 \%$ for soil with (a) sandy, (b) silt loam, and (c) silty clay loam textures.

(a)

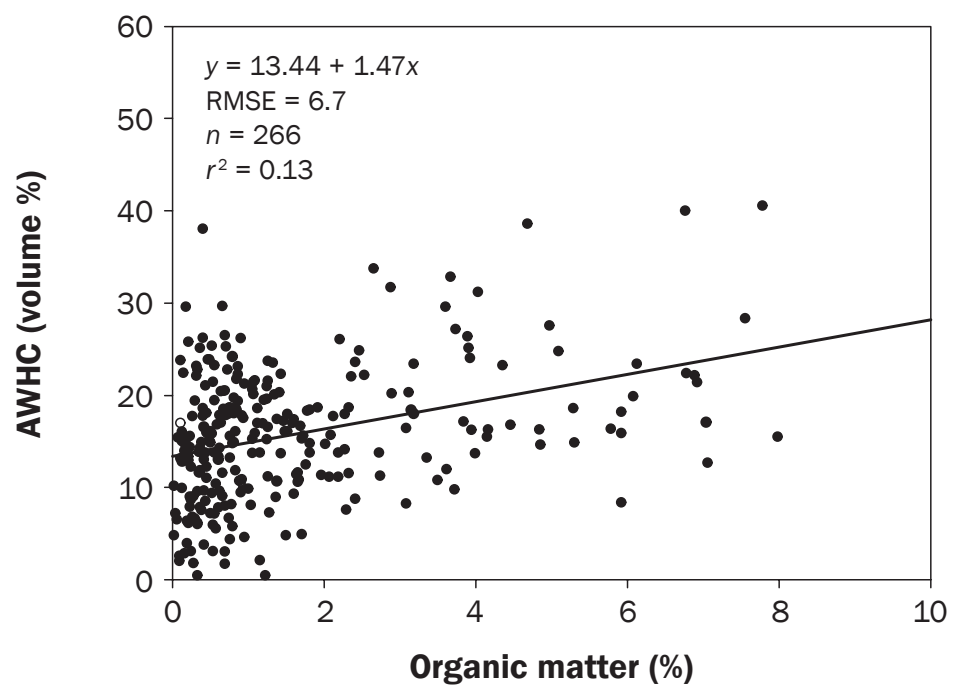

(b)

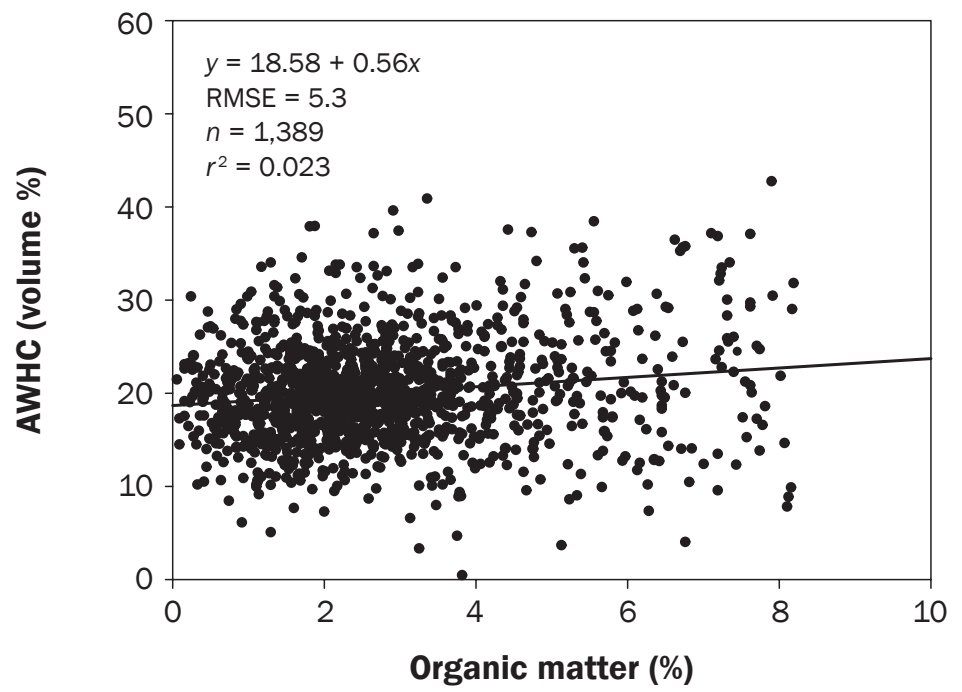

(c)

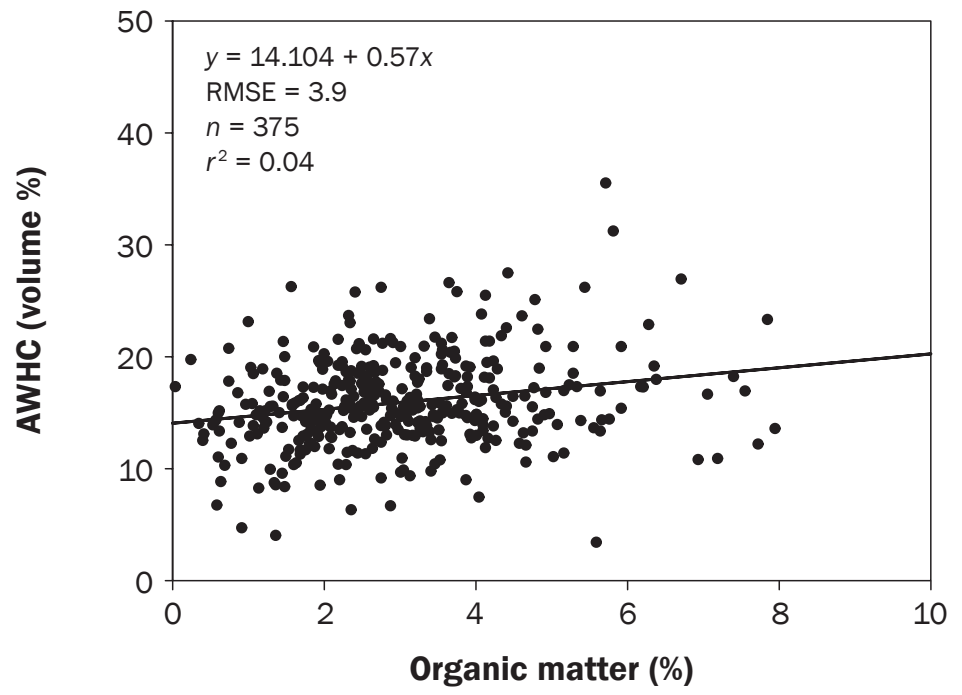

decomposes more slowly (Stott and Martin 1989). Similarly, Six et al. (2002) indicated that clay type (2:1 versus $1: 1$ versus volcanic) plays a role in the stabilization of SOM in soils, but also in the specific surface area present for the water molecules to be adsorbed (Schroeder 1984).

Our study showed that, while the addition of SOM above a certain threshold can increase AWHC, in some cases it can also decrease AWHC. This is not to say that SOM does not positively influence AWHC. Soil organic matter can increase the water infiltration rates of the surface horizons (Jamison and Kroth 1958; Chandrasoma et al. 2016; Packer et al. 1992), mainly due to increases in coarse pore size distribution (Olness and Archer 2005). This, in turn, allows more water to infiltrate and enter the subsoil, where it can recharge the available water (Várallyay 2010). This is especially critical as bigger size and more intense rain events due to climate uncertainty (Trenberth et al. 2003) may lead to rainfall intensity rates greater than soil infiltration rates (Nearing et al. 2005).

\section{Summary and Conclusions}

The general relationship between SOM and AWHC in this study using a large diverse data set showed that, on average, SOM can hold up to 1.0 times its weight in available water. The theoretical calculations indicate that for every $1 \%$ increase in SOM (\% weight), the maximum potential increase in AWHC (vol. $\%)$ is about 1.5 to 1.7 times the amount of SOM (\% weight). This equates to about a $4.5 \%$ to $5.1 \%$ volume increase in available water when SOM in soil increases from $0 \%$ to $3 \%$. This is independently supported by this study, which showed an average increase in AWHC of up to $1.5 \%$ by volume, depending on the texture and clay mineralogy. The increase in AWHC was more pronounced for sandy soils than that for silt loam and silty clay loam soils. In clay soils, the clay mineralogy was a factor in influencing the effect of SOM on increasing AWHC. Soils with a dominance of smectite clays reduced the effect of SOM to AWHC more compared to those with a dominance of kaolinite clays. Soil organic matter can influence water retention in the AWHC range via these different interactions, both directly and indirectly. However, the relationship between AWHC and SOM is complex and involves interactions between amounts of SOM, particle size, clay mineralogy, bulk density, and 


\section{Figure 8}

Soil available water-holding capacity (AWHC) versus soil organic matter range $0 \%$ to $8 \%$ for (a) clay (>40\%) smectitic, (b) clay (>40\%) kaolinitic, and (c) clay (>40\%) mixed soil mineralogy.

(a)

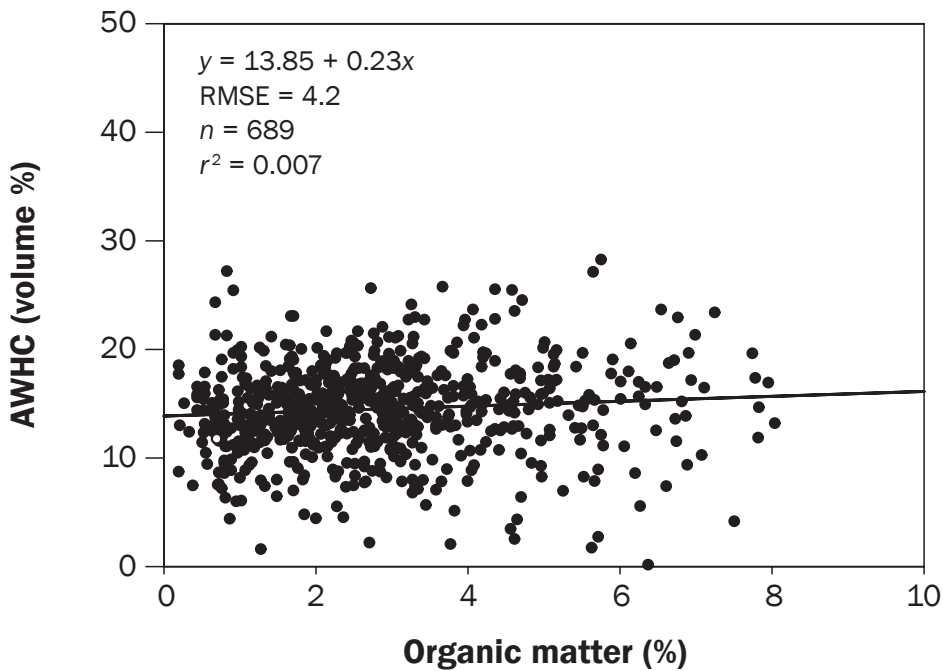

(b)

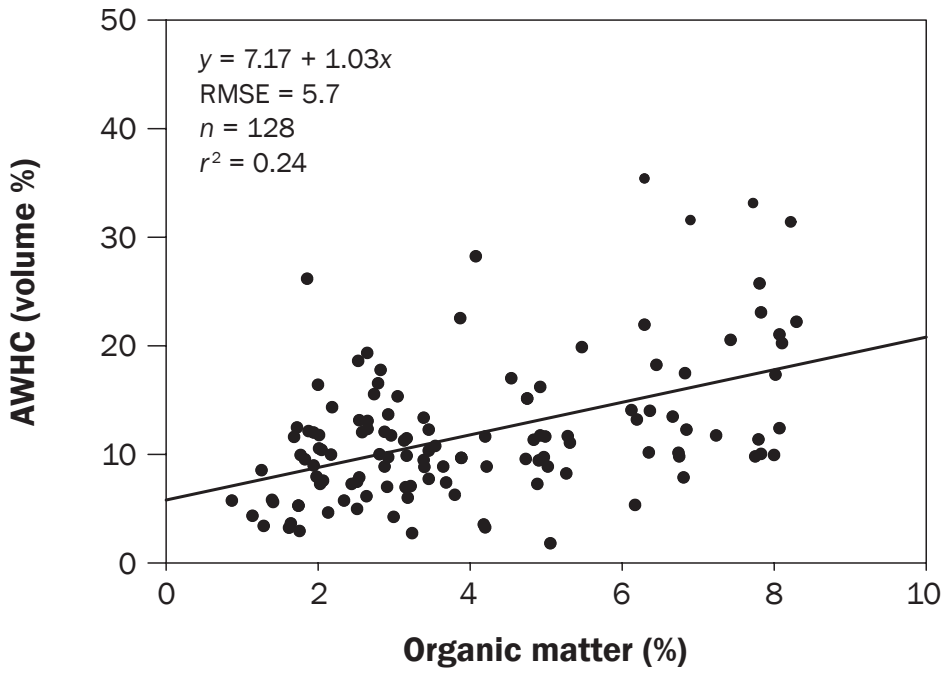

(c)

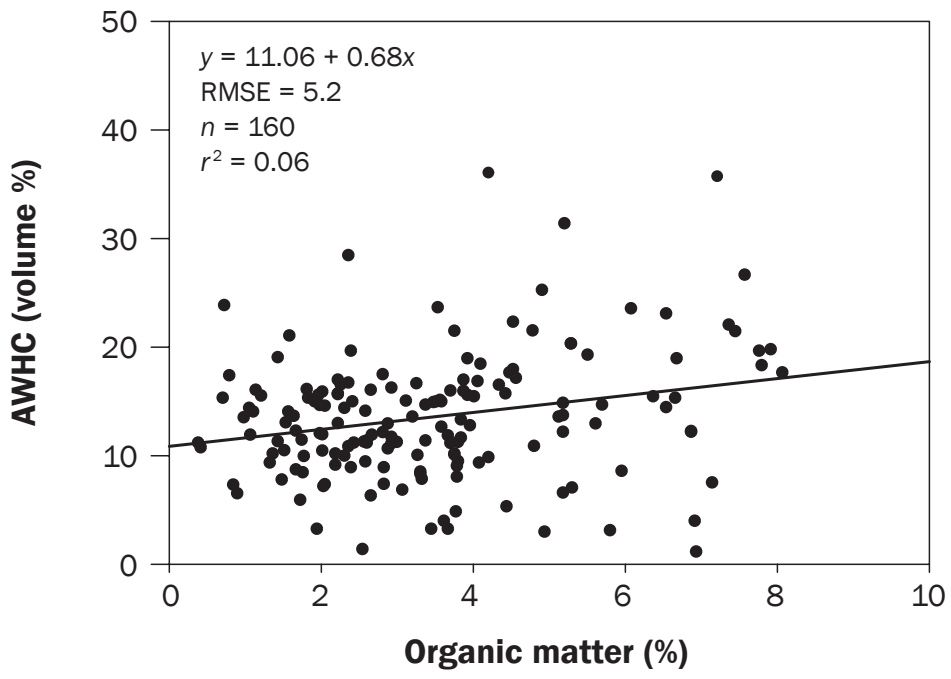

other factors. This study did not directly evaluate the potentially positive effects that increased porosity has on improved infiltration rates, soil structure, and available water recharge, especially for finer texture soils. Further work is needed to understand these complex interactions, especially with regard to the effects that management-induced increases in SOM may have on AWHC.

\section{References}

Barrow, N.J. 1969. The accumulation of soil organic matter under pasture and its effects on soil properties. Australian Journal of Experimental Agriculture and Animal Husbandry 9:437-44.

Bauer, A., and A.L. Black. 1992. Organic carbon effects on available water capacity of three soil textural groups. Soil Science Society of America Journal 56:248-254

Bouyoucos, G.J. 1938. Effect of organic matter on the waterholding capacity and the wilting point of mineral soils. Soil Science 46:377-383.

Brady, N.C., and R.R. Weil. 1999. The Nature of Soil Properties, 12th edition. Upper Saddle River, NJ: Prentice Hall, Inc.

Burt, R. 2011. Soil Survey Laboratory Information Manual. Soil Survey Investigations Report No. 45. Version 2.0. USDA Natural Resources Conservation Service (NRCS), National Soil Survey Center. Lincoln, NE: USDA Natural Resources Conservation Service. https://www.nrcs.usda.gov/wps/portal/nrcs/detail/ soils/research/guide/?cid=nrcs142p2_054165.

Cassel, D.K., and M.D. Sweeney. 1974. In situ soil water holding capacities of selected North Dakota soils. In North Dakota Agricultural Experiment Station Bulletin, Vol. 495. Fargo, ND: North Dakota State University of Agriculture and Applied Science.

Chandrasoma, J.M., R.P. Udawatta, S.H. Anderson, A.L. Thompson, and M.A. Abney. 2016. Soil hydraulic properties as influenced by prairie restoration. Geoderma 283:48-60, doi:10.1016/j.geoderma.2016.08.001.

Cristensen, B.T. 1992. Physical fractionation of soil and organic matter in primary particle size and density separates. In Advances in Soil Science, Vol. 20,1-90. New York: Springer.

Cristensen, B.T. 1996. Carbon in primary and secondary organomineral complexes. In Structure and Organic Matter Storage in Agricultural Soils, ed. M.R. Carter and B.A. Stewart, 97-165. Boca Raton, FL: Lewis Publishers. Emerson, W.W. 1995. Water retention, organic C and soil texture. Australian Journal of Soil Research 33:241-251. Emerson, W.W., R.C. Foster, J.M. Tisdall, and D. Weissmann. 1994. Carbon content and bulk density of an irrigated Natrixeralf in relation to tree root growth and orchard management. Australian Journal of Soil Research 32:939-51. 
Emerson, W.W., and D. McGarry. 2003. Organic carbon and soil porosity. Australian Journal of Soil Research 41:107-118.

Feustal, I.C., and H.G. Byers. 1936. The moisture retaining capacities of peat and soil mixtures. USDA Technical Bulletin No. 532. Washington, DC: USDA.

Hamblin, A.P., and D.B. Davies. 1977. Influence of organic matter on the physical properties of some East Anglian soils of high silt content. European Journal of Soil Science 28(1):11-22.

Hudson, B.H. 1994. Soil organic matter and available water capacity. Journal of Soil and Water Conservation 49(2):189-194.

Jamison, V.C., and E.M. Kroth. 1958. Available moisture storage capacity in relation to textural composition and organic matter content of several Missouri soils. Soil Science Society of America Proceedings 22(3):189-192.

Jury, W.A., W.R. Gardner, and W.H. Gardner. 1991. Soil Physics, 5th edition, 328. Hoboken, NJ: John Wiley \& Sons, Inc.

Knapp, M., K. Price, and N.An. 2012. Comparative vegetation condition report. In $\mathrm{K}-\mathrm{State}$ Agronomy Extension eUpdates, No 357, July 6, 2012. Manhattan, KS: Kansas State University Extension. http://www.agronomy.kstate.edu/documents/eupdates/eupdate070612.pdf.

MAAF (Ministry of Agriculture, Food and Fisheries). 2002. Soil water storage capacity and available soil moisture. Water Conservation Factsheet 619.000-1, Agdex:550. Abbotsford, BC, Canada: British Columbia Ministry of Agriculture, Food and Fisheries.

Mengel, D. 2012. The value of soil organic matter. In K-State Agronomy Extension eUpdates, No. 357, July 6, 2012. Manhattan, KS: Kansas State University Extension. http://www.agronomy.k-state.edu/documents/ eupdates/eupdate070612.pdf.

Naeth, M.A., A.W. Bailey, D.S. Chanasyk, and D.J. Pluth. 1991. Water holding capacity of litter and soil organic matter in mixed prairie and fescue grassland ecosystems of Alberta. Journal of Range Management 44(1):13-17.

Nearing, M.A.,V. Jetten, C. Baffaut, O. Cerdan, A. Couturier, M. Hernandez, Y. Le Bissonnais, M.H. Nichols, J.P. Nunes, and C.S. Renschler. 2005. Modeling response of soil erosion and runoff to changes in precipitation and cover. Catena 61(2):131-154, https://doi.org/10.1016/j. catena.2005.03.007.

Olness, A., and D. Archer. 2005. Effect of organic carbon on available water in soil. Soil Science 170(2):90-101, doi:10.1097/01.ss.0000155496.63323.35.

Packer, I.J., G.J. Hamilton, and T.B. Koen. 1992. Runoff, soil loss and soil physical property changes of light textured surface soils from long term tillage treatments. Soil Research 30(5):789-806.

Rawls, W.J., D.L. Brakensiek, and K.E. Saxton. 1983. Estimation of soil water properties. Transactions of the American Society of Agricultural Engineers 25(5):1316$1320,1328$.
Rawls, W.J., Y.A. Pachepsky, J.C. Ritchie, T.M. Sobecki, and H. Bloodworth. 2003. Effect of soil organic carbon on soil water retention. Geoderma 116:61-76, doi:10.1016/ S0016-7061(03)00094-6.

Romano, N., and A. Santini. 2002. Water retention and storage: Field. In Methods of Soil Analysis: Part 4Physical Methods. SSSA book series no. 5, ed. J.H. Dane and G.C. Topp, 721-736. Madison, WI: Soil Science Society of America, Inc.

Rose, D.A. 1991. The effect of long-continued organic manuring on some physical properties of soils. In Advances in Soil Organic Matter Research, ed. M.S Wilson, 197-205. Amsterdam: Elsevier.

Rühlmann, J., T.M. Korschensb, and J. Graefe. 2006. A new approach to calculate the particle density of soils considering properties of the soil organic matter and the mineral matrix. Geoderma 130:272-283.

Russell, M.B.,A. Klute, and W.C. Jacob. 1952. Further studies of long-time organic matter additions on the physical properties of Sassafras silt loam. Soil Science Society of America Proceedings 16:156-9

Russell, J.S., and R.C. Shearer. 1964. Soil fertility changes in the long-term experimental plots at Kybybolite, South Australia. Australian Journal of Soil Research 15:91-9.

Salter, P.J., and F. Haworth. 1961. The available-water capacity of a sandy loam soil. II. The effects of farmyard manure and different primary cultivations. Journal of Soil Science 12:335-42.

Schroeder,D. 1984. Soil-Facts and Concepts.Translated from German and adapted by P.A. Gething. Bern, Switzerland: International Potash Institute. ISBN:3-906535-01-0.

Six, J., R.T. Conant, E.A. Paul, and K. Paustian. 2002. Stabilization mechanisms of soil organic matter: Implications for C-saturation of soils. Plant and Soil 241:155-176.

Soil Survey Division Staff. 1993. Soil Survey Manual. 2nd edition. Agricultural Handbook 18. Washington, DC: US Government Printing Office.

Soil Survey Staff. 1999. Soil Taxonomy: A Basic System of Soil Classification for Making and Interpreting Soil Surveys, 2nd edition. Agricultural Handbook 436 Washington, DC: US Government Printing Office.

Soil Survey Staff. 2014. Kellogg Soil Survey Laboratory Methods Manual. Soil Survey Investigations Report No. 42,Version 5.0, ed. R. Burt and Soil Survey Staff. Lincoln, NE: USDA Natural Resources Conservation Service.

Soil Survey Staff. 2017. Gridded Soil Survey Geographic (gSSURGO) Database for the Conterminous United States. Washington, DC: USDA Natural Resources Conservation Service. https://gdg.sc.egov.usda.gov/.

SSSA (Soil Science Society of America). 2008. Glossary of Soil Science Terms. Madison, WI: Soil Science Society of America.

Stevenson, FJ. 1994. Humus Chemistry: Genesis, Composition, Reactions. Hoboken, NJ: John Wiley \& Sons, Inc.
Stone, J.T., and C.S. Garrison. 1940. Relationship between organic matter content and moisture constants of soils. Soil Science 50:253-256

Stott, D.E., L.F. Elliot, R.I. Papendick, and G.S. Campbell. 1986. Low temperature and low water potential effects on the microbial decomposition of wheat residue. Soil Biological Biochemistry 18:577-582.

Stott, D.E., and J.P. Martin. 1989. Organic matter decomposition and retention in arid soils. Arid Soil Research Journal 3(2):115-148, http://dx.doi. org/10.1080/15324988909381195.

Trenberth,K.E., D.Aiguo, R.M.Rasmussen, and D.B. Pearson. 2003. The changing character of precipitation. Bulletin of American Meteorological Society 84(9):1205-1217, doi:10.1175/BAMS-84-9-1205.

Várallyay, G. 2010. The impact of climate change on soils and on their water management. Agronomy Research 8 (Special Issue II):385-396. 